\title{
THE INTERPLAY BETWEEN NATIONAL INTEREST AND IDEALISM REGARDING SWEDEN'S GRIPEN EXPORTS
}

\section{Wayne Coetzee \\ School of Global Studies, University of Gothenburg ${ }^{I}$}

\begin{abstract}
The study on which this article is based, aimed to map out and analyse the ways in which Sweden's Gripen exports have been shaped and sustained since the end of the Cold War. It did so by examining three interrelated factors that have had an effect on Sweden's defence industry. By illustrating how societal preferences, defence and security policy shifts, and the role of national identity have influenced weapons manufacturing and exports, this article provides a balanced overview of the most salient push and pull factors of Sweden's Gripen exports. The central contention of the study was that Swedish weapons manufacturing and exports often involve a close interaction between interests and ideals. Moreover, due to the multitude of richly correlated, interconnected and mutually reinforcing elements related to such practices, there cannot be a neat and parsimonious distinction between agents and structures and domestic and international settings. Instead, the study was especially reflective of real-world practices and the strategic relational approach between those forces that shape and sustain Sweden's Gripen exports.
\end{abstract}

\section{Introduction}

Sweden's SAAB-manufactured ${ }^{2}$ JAS $^{3}$ Gripen fighter exports have witnessed considerable success in one of the world's most competitive and sophisticated markets. Deals with South Africa, the Czech Republic, Hungary, Thailand and Brazil - as well as potential deals with other nations ${ }^{4}$ - have illustrated that the Gripen is a powerful global contender. ${ }^{5}$ However, unlike most major

Scientia Militaria, South African Journal of Military Studies, Vol 45, No. 1, 2017, pp. 45-66. doi : 10.5787/45-1-1195 Creative Commons License-CC BY NC-ND 4.0 weapons exporters of advanced fighter jets, Sweden is a small country in Northern Europe with a strong tradition of neutrality and military non-alignment that lacks relative material power in the international domain. It has also not been at war with 
another state since 1814, marking one of the longest uninterrupted periods of peace experienced by any nation in the world. ${ }^{6}$ Given these aspects, how can we understand Sweden's Gripen exports?

The development, production and export of a product such as the Gripen are, after all, no ordinary undertaking. It is a comprehensive national commitment that requires, amongst other things, "extensive industrial inputs from such sectors as steel, metallurgy, machinery, and electronics", 7 innovative research and development (R\&D), and state intervention and market facilitation. The incremental development of this national system has become extremely well integrated into Swedish society in political, economic and technological terms and the decisionmaking structures that underlie such a system. ${ }^{8}$ To this, we may add that such a national system has also become ideologically embedded within society through the preference shaping of societal and state actors.

By taking into consideration the various push and pull factors that have influenced Sweden's weapons exports, the study on which this article reports, aimed to understand the forces that have shaped and sustained Sweden's impetus and capacity to produce and export the Gripen. To that end, the study examined three interrelated factors: societal preferences, domestic policy shifts vis-à-vis defence and security, and the role that national identity plays in Sweden's weapons exports. The empirical findings are based on elite interviews and archival work that was conducted between September 2012 and May 2016 as well secondary literature on Swedish foreign policy and arms trade.

The article proceeds as follows: first, I examine the configuration and variation of societal preferences vis-à-vis weapons manufacturing and exports, and how these preferences are aggregated through the domestic political system. Such a discussion opens up the black box of the state and it reveals who the domestic winners are from the production and trade in weapons such as the Gripen. I then outline some of the main changes in Swedish defence and security policies and practices since the end of the Cold War. These changes, it is argued, have had a salient effect on the Gripen programme. Moreover, this section illustrates the important role that the state plays in market facilitation and commercialisation of the Gripen. In the following section, attention is turned to the paradoxical yet effective role that national identity plays in Swedish weapons manufacturing and exports and how the Gripen occupies a special albeit dual role in this setting.

\section{Societal preferences}

In the Swedish political system, societal actors, such as industry and trade 
unions, have assumed an important role in championing $R \& D$, manufacturing and export of defence material. These societal actors have traditionally pressured government to act in the interest of their shareholders and constituents respectively. ${ }^{9}$ The private economic and political interests of these societal actors are transmitted to the state through various representative platforms that often privilege some voices over others.

\section{Industry preferences}

The defence industry in Sweden generally behaves in a strategic manner in order to benefit private gain. Maximising profits often surpasses the need to seek other social goals. Profits mean that the defence industry can compete internationally and remain important domestically. A director at Sweden's Security and Defence Industry Association (SOFF), succinctly explains the defence industry's preferences in this regard:

The defence industry, similar to other industries in Sweden, is heavily focused of market access. Without exports the Swedish defence industry will not survive. Seventy per cent of Swedish produced arms are exported. You must understand that exports are not only politically strategic they also have a common sense economic logic of selling to make profit and survive. At the end of the day, the defence industry goes where the money is just like any other business. ${ }^{10}$

To succeed, the defence industry places significant pressure on government to act in their interests. As Former Minister of Defence, Björn von Sydow, notes, "companies such as SAAB are all the time [sic] demanding action or demanding answers from government. They are constantly demanding yes or no from the government for exports and international collaboration". ${ }^{11}$ Former Prime Minister, Ingvar Carlsson, concurs with such an assessment and argues, "companies like SAAB have always placed extreme pressure on the government. They take this position, which is that they must be allowed to export to countries and the government must make that a reality". ${ }^{12}$

The preferences of the defence industry are similar to those put forward by Sweden's large industrial base. That is because these sectors are not separate entities per se. Since the 1940s, industrial giants such as Volvo, Scania, SAAB, Electrolux and Ericsson - normally associated with the manufacturing of cars, trucks, microwave ovens and telecommunications (amongst other things) - have produced defence components. Economic interdependence in this instance has thus meant that 
there is a parallel impetus for market access to export Swedish-made defence material.

\section{Trade union preferences}

In conjunction with the defence industry and industrial base that pressures government for favourable policies vis-à-vis arms manufacturing and export, trade unions have played an equally important role. Trade unions act in the interests of their constituents, that is, the workers employed in the defence industry. Any analysis of the Swedish defence industry that overlooks the central role that trade unions have played is essentially incomplete. As Björn von Sydow remarked, "trade unions, specifically those that organise defence industry employees, are very important for a model that explains why the defence industry operates the way it does and why it has the type of interests it does". ${ }^{13}$ The most powerful and politically influential trade union with a vested interest in the defence sector is IF Metall (IFM). With an estimated 320000 blue-collar workers, IFM is one of the largest trade unions within the private sector in Sweden. It is responsible for workers in 11600 workplaces and most workers in the defence industry are represented by IFM. ${ }^{14}$

IFM has two core objectives: high employment, and good working conditions for its members. For these two objectives to be realised, the Swedish defence industry and industrial base must be competitive and it must enjoy favourable government policy. IFM has had close relations with the Social Democrats (SAP) ${ }^{15}$ since the 1930s in order to achieve these and other core objectives. ${ }^{16}$ Concerning weapons manufacturing and exports, IFM as well as their political representative, the SAP, often find themselves in an awkward balancing act between ideals and interests.

On the one hand, IFM takes a strong ideals-driven position on weapons export controls and supports a restrictive arms trade policy, especially to so-called developing countries, such as South Africa, Brazil and India. Swedish trade unions have had strong relations with these countries for decades ${ }^{17}$ but it has also been at the forefront of championing Gripen deals with each of these countries. On the other hand, IFM actively supports the defence industry because it provides thousands of jobs for its members. ${ }^{18}$ This form of doublethink, i.e. simultaneously protecting and representing the interests of their members whilst also championing a restrictive arms trade policy has become status quo in Sweden. A former special adviser to the Minister of Defence, explains that this form of doublethink is, however, a classic case of the pragmatism trumping principle: 
It is important to understand that IF Metall defend the interests of the defence industry because of their own self-interest. They are part of framing the kind of hard hawkish faction in the Social Democratic party in terms of defence. They are hawkish on defence and they have always been hawkish on defence. When it comes to the defence industry, and in particular the Gripen programme, it is definitely more about self-interest from their side. It fits more clearly into a hawkish narrative where the key is self-interest. ${ }^{19}$

\section{Aggregating societal preferences through the political system}

Having considered the most influential societal preferences regarding the manufacturing and export of the Gripen, this section discusses the manner in which these societal preferences are transmitted to the state. By identifying the nature of the practices that shape and guide domestic political representation, one can gain a better understanding of how powerful domestic groups or coalitions dominate this policy area.

\section{Revolving door}

It is now common knowledge and even openly discussed in government corridors that elites with vested interests in Sweden's defence industry enjoy a high level of mobility between public, private and civil society sectors. A salient example is that leaders from IFM regularly move into politics to obtain strategic positions in the SAP and vice versa. Members of the SAP and other major political parties also frequently secure top positions at $\mathrm{SAAB}$ and companies connected to the defence industry. ${ }^{20}$ The same is true for top-ranking military personnel who move into the defence industry where they occupy strategic decision-making positions. The revolving door policy ensures that there is a circulation of knowledge, ideas and interests regarding the development, manufacturing and exports of the Gripen. This "epistemic community" 21 frequently reinforces the importance of a strong defence industry in Sweden as well as the need to uphold the rate of production and exports. ${ }^{22}$

\section{Lobbying}

Lobbying has become an essential part of the political system in Sweden visà-vis defence. ${ }^{23}$ That said, arms-related lobbying in Sweden differs from the conventional 'American style' lobbying usually associated with the militaryindustrial complex. ${ }^{24}$ A former special advisor to the Prime Minister provides a personal insight into how lobbying functions in Sweden regarding arms manufacturing and exports: 
Lobbying in Sweden is different [from lobbying in the United States of America] because it takes place in a very structured environment. Folk och Försvar, ${ }^{25}$ they have this meeting every year where people from politics, from industry, from the military forces, from the unions, and even from the media meet. This is an area for lobbying to take place. It is not the kind of classic lobbying that takes place where people are paid to make a campaign or anything, there is no huge amounts of money involved for example. People might buy each other a beer or something like that. Money is not the driving force here; social structures and social networks are the driving force. They talk to each other, they understand each other, and they find common ground. This is not only for the armed forces and politicians; it is also for industry and unions. These two have a kind of natural role in that social universe. By the way, the Gripen's manufacturing and exports are often front and centre during these discussions. ${ }^{26}$

\section{Corporatism}

Paradoxically, the Swedish Welfare State - mainly under the reigns of the SAP - has made it possible for "substantial involvement of interest groups in the policy-making and the implementation of public affairs. In particular, the main labour market organisations - trade unions as well as the employer's organisations" have been "major political players in the formation of governmental policy" ${ }^{27} \mathrm{By}$ using the Red/Green alliance (SAP and Green Party) government as an example, a senior official at IFM explains how this trade union infiltrates the political structure in Sweden to strengthen its representation in the domestic policymaking system and how it then influences political decision-making regarding its interests:

In the current parliament, there are 349 seats. 138 of those seats are Social Democrats and Green Party members. The Prime Minister today is a Social Democrat but he is also IF Metall's former president. Almost half of the Social Democratic seats are trade unionists. If we look at the leadership in the party, three out of the seven of the senior leader group are IF Metall. If you look at the extended group of leaders in the party, there are six IF Metall members in that leadership group. If it comes to some of the key figures in the Social Democratic party over the years, the leaders, and the top positions, many of them have come from our trade union. Because IF Metall has so much power, we try to use this in different ways. We always try to influence the parliament and we always try to have close contacts with individual parliamentarians. When it comes to making some kind of a decision, let's say they want to make some change to some kind of Act or policy; they 
always turn to us. This is also how we put forward our preferences for defence-related matters through the parliament and in discussion with the government. ${ }^{28}$

Despite suggestions that corporatism has declined in Sweden since the end of the Cold War ${ }^{29}$ it still plays a significant role in defence-related matters. Formal institutional changes may have taken place in recent times but the interests and norms that underlie socio-political partnerships regarding weapons manufacturing and exports are mostly intact. More importantly, instead of being a separate process, corporatism has laid the foundation for and is deeply entangled with the revolving door and lobbying practices discussed above.

\section{Policy shifts}

Although the Swedish government accepted an enhanced understanding of security after the Cold War, inter alia, the acknowledgement of human security as supposed to the narrowly defined military conception thereof, ${ }^{30}$ preference has nevertheless been given to state-level security, which is expressed most notably through the manufacturing and export of conventional war material such as the Gripen. The export of the Gripen has essentially become an extended arm of the Swedish government's foreign policy. Based on Sweden's security doctrine over the years, the view is that the Gripen can act as a strategic deterrent to potential aggressors in the region and could do the same for those countries that procure these planes. ${ }^{31}$ However, this should be understood in the context of Sweden's own ideational assessment of the role of its armed forces and military equipment internationally. As a defence advisor to the government remarks, "we view the Gripen as a plane made for peace, not for war". ${ }^{32}$

\section{Armed neutrality}

The concept of neutrality lies at the core of any enquiry into why and how Sweden has built up an entire system of security provision both domestically and abroad - a system that makes it possible to manufacture and export the Gripen. A cornerstone of Sweden's neutrality was the pragmatic policy regarding selfsufficiency of armaments that was pursued and which led to the creation of a large defence industry (even in an international perspective) ${ }^{33}$ and a self-supporting military capable of defending the entire Swedish territory. ${ }^{34}$

Due to Sweden's geographic proximity to the Soviet Union, it had to be in a position where it could defend itself in case of an attack during the Cold War. In such an event, the assault would have to be halted before the attacker reached the 
border of Sweden. This required forward defence capabilities, which explains why Sweden focused most of its efforts to create an advanced air force and navy. ${ }^{35}$

\section{Post-neutrality}

Since the end of the Cold War, Sweden has entered into a phase of nonaligned "post-neutrality" 36 where the previous emphasis on a large conscripted territorial defence force has gradually given way to an increasing focus on international military operations in collaboration with the United Nations (UN), the European Union (EU) or the North Atlantic Treaty Organization (NATO). ${ }^{37}$ In addition, while Sweden has long been a loyal contributor to traditional 'Blue Helmet' peacekeeping missions in the past, there has also been an increased political willingness recently to commit Swedish military forces to international expeditionary operations. ${ }^{38}$ Evidence of this new, more active stance could be seen in the deployment of a Swedish Air Force detachment (using the Gripen) to help uphold the no-fly zone over Libya in 2011 as part of Operation Unified Protector. This military operation provided the Gripen with a sense of legitimacy in the international domain because fighter aircrafts are usually judged by their record of accomplishment in conflict situations. ${ }^{39}$ Before 2011, the Gripen had not been tested in combat, and this created some difficulties in justifying its credibility. As Sweden's Defence Research Agency (FOI) explains:

Most aircrafts that have competed with the Gripen for tender processes since the end of the Cold War have been battle-proven. Before 2011, the Gripen had never seen any real combat action. But after the Gripen participated in operations in Libya, it provided the plane with a stronger marketing profile. What this basically comes down to is that it did not allow the Gripen's competitors to do what they have done previously, which was to argue that the Gripen has never been combat-proven and that it is only a product that is for show. If, in the future, the Gripen is in more serious combat situations then that will make an even stronger case for the plane. ${ }^{40}$

\section{Cooperation and marketisation}

The need for weapons exports after the Cold War ignited a broad discussion in Sweden for how the process of arms supply could be more efficient. ${ }^{41}$ The government favoured the efficiency of the market, and with market principles dictating matters, weapons manufacturing and exports became more commercialised. ${ }^{42}$ Through a series of government decisions to deregulate and denationalise the defence industry, Swedish companies such as Bofors, Hägglunds, 
Kockums and SAAB were sold whole or in part. ${ }^{43}$ Internationalisation of this sort was acknowledged by the government as being central to defence restructuring in Sweden. This was evident in a 1998 government report to parliament regarding Swedish exports of military equipment:

The increasing internationalisation that characterises many sectors of society is also evident in the arms area. A rationalisation of the European defence industry has begun, involving a considerably greater measure of transboundary industrial cooperation in the defence area than has traditionally been the case. The reason for this is to be found, inter alia, in the end of the Cold War, which has signified a changed threat scenario, and in most countries reduced economic frameworks for procurement of military equipment. Shrinking resources and substantially rising development costs for each new generation of military equipment have given rise to an awareness in most European countries with significant arms industries that purely national defence industries can no longer be maintained for economic reasons. ${ }^{44}$

In essence, the end of the Cold War softened the government's stance vis-àvis defence cooperation and it allowed companies such as SAAB to step out of the shadows of "secret cooperation" 45 and capitalise on the benefits of an unguarded interdependence - not only with the West, but also with emerging markets.

Before the new defence budget was released in 1999, it was also suggested that the government take stronger measures to support the conversion of "military industries to civilian production". ${ }^{46}$ Civil-industrial cooperation was a way out of economic and technological constraints. Such a conversion meant, for the most part, that the civilian side of the defence industry would manage R\&D. The aim was that defence-related technologies could be used or converted into products and services for civilian use meaning larger returns on government-backed investments. In the case of the Gripen programme, cooperation and marketisation have been preferential for the Swedish government for three reasons:

- Cooperation increases deeper understanding for the demands of foreign buyers, especially those outside of Europe. It also creates the opportunity to manufacture customised versions of the Gripen for foreign buyers. With such adaption and variation the plane has become more appealing to potential clients, thus making marketing easier. ${ }^{47}$ This has provided the Gripen with a critical edge over many of its competitors, especially the fact that it can be manufactured with the capability to carry out flight operations from undeveloped airstrips - an attractive feature for clients in so-called 'developing countries'. 48 
- Cooperating with other defence firms provides companies such as SAAB with greater international market access. Exports would not only generate revenue and ensure longer production runs; it would also help to preserve important competence in the defence industry. ${ }^{49}$ This is why the 1999 Gripen deal with South Africa was so important. Being the first overseas customer to procure the plane, South Africa would become a vital testing ground for the Gripen programme. As Åke Svensson, former president of SAAB, acknowledged, "the success of future negotiations with other countries depends to a degree on the performance of the aircraft in South Africa". ${ }^{0}$

- The Gripen programme is the most expensive and largest industrial project ever undertaken by Sweden. ${ }^{51}$ The rapid development of the technology used for the Gripen pushed up the R\&D content and costs making it increasingly more difficult to finance the programme on a national basis. Cooperation with other partners significantly brings down the development costs, and as was seen elsewhere in Europe, cooperation reduces defence expenditures "by amortizing the enormous fixed capital and R\&D investments of high-technology weapons production over longer production runs". 52

\section{The state as agenda setter and intermediary}

The state has a dual role to play in terms of maintaining the indigenous defence sector that manufactures the Gripen. It does so by being a consumer of the produced goods - in other words creating a market for goods - and by being a marketing agent for the defence industry. ${ }^{53}$ In short, without the state as a customer and market creator there will be no defence industry in Sweden. ${ }^{54}$ In the mid-1990s, the Swedish government proposed increased support and marketing for defence industry products. The 1996 Bill on the Renewal of Swedish Defence clearly instructed government officials and agencies to support the export of Swedish arms:

Tougher competition on the export markets has made it more difficult for Swedish companies to grasp export opportunities. It is established in the bill that if it is to be possible to utilize the export potential of Swedish companies, the government and Swedish authorities must actively and in a structured way support the export endeavours of the defence industry to undertake major defence matériel projects, on condition that these endeavours are in line with the guidelines for exports for military equipment. ${ }^{55}$

Davis explains how the government implemented this policy vis-à-vis the Gripen:

First, a group for defence industry matters and exports of military equipment was formed at State Secretary level [...] with the aim of promoting exports 
of military equipment to approved countries. Second, an ambassador was appointed within the Ministry of Trade (Handelsdepartementet) as a 'marketing supremo' for major systems such as the Gripen and submarines [...] Third, although Swedish embassies were specifically told in the past not to play a marketing role, following the appointment of the marketing supremo they have now been asked to play a support role and, more specifically, have been told to go out and find partners for Swedish projects. In many respects the Gripen project is an illustration of this change of thinking. ${ }^{56}$

Because the state relies heavily on the defence industry to provide arms for national defence, jobs, and new technologies, it provides the defence industry with a certain measure of economic security. ${ }^{57}$ As Ingvar Carlsson concluded, the state has a vested interest in "preserving the indigenous industrial base that produces the Gripen due to national interests". 58

\section{Political consensus}

In addition to the ostensibly internationalist outlook discussed above, the ongoing assessment of the policymaking elite is that Sweden would be politically weakened internationally if it did not develop, manufacture and export high-tech conventional weapon systems such as fighter jets and submarines. In that sense, the policymaking elite are effectively playing to two audiences: the first audience represents its popular constituency that has become accustomed to the ideological ties their country have to neutrality. The second audience consists of the more hawkish elements within the state-military apparatus that views Sweden's future as intrinsically tied up with Europe and its North American allies, and as a regional power that needs to be strong militarily.

Despite widespread moral discomfort with Swedish arms exports, ${ }^{59}$ there has been less resistance against such practices in recent years, particularly in political circles. In fact, "since the late 1990s, interests in arms trade critique have been dwindling and the number of members in the Swedish parliament with roots in the peace movements have been reduced significantly". ${ }^{60}$ Political parties have also had a large degree of consensus on defence industry matters since the end of the Cold War. Among the political parties, the SAP, the conservatives (Moderaterna), the Centre Party (Centerpartiet), and the liberals (Folkpartiet) have been ideologically aligned in this regard. ${ }^{61}$ Such widespread consensus has effectively led to the institutionalisation of arms trade in Sweden. As one senior Member of Parliament observed: 
Sweden has basically become a militarised society. Most of the political parties, except for the Left Party, are obsessed with weapons. Even those politicians that say they are opposed to arms trade ideologically, such as the Green Party for example, rationalise the need for the military system we have in Sweden. This is particularly true when it comes to the sale of the Gripen. ${ }^{62}$

\section{The role of national identity}

Insofar as neutrality and non-alignment have become part of "Swedishness", ${ }^{63}$ so too has the manufacturing and export of the Gripen. Sweden's ability to market itself successfully as a 'good partner' has been a major pull factor for potential cooperating partners. The mainstay of this national identity is twofold. On the one hand, it is based on Sweden's perceived idealist-driven foreign policy that has been pursued since the 1960s. Such a policy has consisted, amongst other things, of -

- the support of various liberation struggle movements against colonialism and apartheid;

- the use of international organisations, such as the UN, to promote universal values;

- $\quad$ very generous aid and socio-economic development projects in the Global South; and

- the ability to act as a mediator and bridge-builder during conflicts.

Coupled with Sweden's progressive domestic policies, these ideals-driven factors provide a potent political cocktail for the preference shaping of other countries.

On the other hand, Sweden's national identity is based on its ability to manufacture sophisticated, affordable and reliable products. Swedish companies have built an international reputation for producing high-quality goods and services, which have been made possible by the country's large and very successful industrial base - one that places a high focus on technological know-how. This has led to a situation where Sweden has dominated niche markets for several years, specifically in the aeronautics sector - one of its main areas of comparative advantage. Hence, Sweden's defence material is attractive to potential clients because the products reflect the technological abilities shown by Swedish engineers and scientists. "This is evident in the high number of $\mathrm{PhD}$ students working within the technical/engineering field, one of the highest per capita ratios in the world". ${ }^{64}$ 
Most weapons-exporting nations use their national identity to sell arms in one way or another. However, as a White House defence advisor in Washington DC remarked:

Sweden has become very good at using its image to sell weapons, probably better than anyone else. Their success lies very much in the fact that buying nations usually assume that they are the good guys and everyone else are the bad guys. ${ }^{65}$

Consequently, Sweden has succeeded to provide an unorthodox alternative for potential weapons-trading partners, especially small and emerging powers.

During the time of great power politics, the world's hegemons used arms exports as either coercive diplomacy ${ }^{66}$ or to strengthen relationships with regional allies. ${ }^{67}$ Smaller non-neutral nations often had little choice but to align with powerful factions for strategic security, political and economic reasons. However, the end of the Cold War ushered in a new era where small and emerging powers increasingly took control of their own destinies. The IBSA countries (India, Brazil and South Africa) have been amongst those that have attempted to pose real alternatives to the current world order. ${ }^{68}$ A major conventional arms deal with Sweden provides these regional powers and smaller nations with the potential agency to achieve more autonomy and to project their power free from the constraints of the traditional world powers.

Procuring military hardware from a non-aligned country in the post-Cold war era means that there is potentially far less political baggage involved than when procuring from major weapons-exporting countries. As one Swedish government official put it, "security policy implications are often more important than price. If you buy from the Americans there are lots of security policy implications." ${ }^{69}$ In addition to Sweden's peace dividend, and unlike most other major weapons exporters, it also does not have a notable colonial history. Emerging economies in the Global South are particularly cautious of military alliances with major powers with colonial histories. ${ }^{70}$

The assumption is thus that where, how and by whom the product is manufactured is just as important as its functionality and price tag. Hence, purchasing fighter jets from Sweden does not only fulfil a defence/technical role; it also embodies a socio-political constructed meaning. After all, technology is never just technology: "every machine has a socially constructed meaning and a socially orientated objective [...] technological developments can never be fully understood or predicted independently of their social context". ${ }^{71}$ 
Domestically, the Gripen has become a symbol of national prestige, symbolic power, accomplishment and identity. As a former foreign policy advisor to the Swedish Prime Minister observed, "our defence industry has become very good at making high-tech and niche products, it is part of who we are. Like it or not, a product like the Gripen has become part of Sweden's national identity." 72 However, the Gripen seems to occupy a special place in Sweden's national identity inventory. It is one of the few weapon systems with which Swedes comfortably identify. The following striking expression by one of the leading Gripen experts in Sweden provides a rare insight into this mind-set:

Politicians are more comfortable with sales in the aeronautics sector because it is not problematic. It is much better for our Prime Minister to sell the Gripen than selling canons. He does not want to stand in front of a canon and look happy. I mean, canons or small arms are a more clear sign of selling death. Besides, these things have such a bad reputation internationally. The Gripen, on the other hand, is slick, it is sexy, and every boy would love such a toy. ${ }^{73}$

Masculine-infused rhetoric of this nature is commonplace in discussions on the Gripen. Consider, for example, suggestions that the Gripen demonstrates to other nations that Sweden is:

- a "great power in the world", 74

- a "state to be feared"; ;5

- a "very able regional power that can defend its own territory"; 76

- a "state that is respected by others because it has the capacity to manufacture fighter jets", 77

- a country that is "important in the world because it has advanced military technology"; 78

- $\quad$ and the most recent assumption that the manufacturing and export of the Gripen has helped Sweden to have a larger say in the affairs of others and be more influential internationally. ${ }^{79}$

The abovementioned assertions regarding national identity in the context of the Gripen stand in stark contrast to other, more common national identity labels, such as "moral hegemon", 80 "moral superpower", ${ }^{81}$ or "conscience of the world" ${ }^{82}$ Interestingly, when these same societal and state actors refer to the export of the Gripen, they often conflate these two identities. The Gripen deal with South Africa illustrates this point rather well.

One of the main aims of Sweden's foreign policy towards post-apartheid South Africa was to combat inequality and rectify historical injustices. ${ }^{83}$ Those in Sweden who were championing the exports of the Gripen suggested that the deal 
would be broadly in line with Sweden's values-driven foreign policy. For example, parliament spokesperson for the SAP, Leif Pagrotsky, and SAAB's former chief executive officer (CEO), Jan Närlinge, explained that the deal would benefit poor black South Africans ${ }^{84}$ and in particular black women who would have the opportunity to become South African Air Force pilots and fly the Gripen. ${ }^{85}$ Similar arguments were made in parliamentary debates and the government argued that the decision to export the aircraft was in fact ultimately in line with South Africa's broader development goals. ${ }^{86}$ This case illustrates that, despite the blatant and at times puzzling realpolitik utterances illustrated earlier, there remains a strong idealsdriven thrust in the manufacturing and export of the Gripen. Another salient example that stands out in this regard is Sweden's generous offset agreements and technology transfers. ${ }^{87}$

Offset agreements require the seller country (Sweden) to reinvest weapons sales proceeds in the purchasing country. These so-called 'offsets' offer significant benefits to developing countries in various ways, the most common being promoting and investing in industrial activity. Such agreements also reduce the procurement cost of the buying nation. ${ }^{88}$ By the same token, Sweden is one of the few major weapons exporters in the world that have offered to be extensively involved in the production and maintenance of procured weapons systems through offering extensive technology transfers. Buyers in developing countries see the importance of technology transfers as critical to future economic development and prosperity, as well as a tangible way to build their own competencies. ${ }^{89}$ Hence, "technology transfers for these countries are often more important than the price of the plane", 90 as one Swedish government official observed.

There is a widely held assumption in Sweden by powerful societal and state actors that Swedish weapons will serve the buying country, especially those in the Global South, better than other more 'aggressive partners'. This has become a key bargaining plank against domestic resistance because these elites argue that weapons exports are a vehicle for socio-economic development in buying countries. ${ }^{91}$ The primary logic at play here is that Sweden requires a healthy security infrastructure to spread wealth, knowledge and development in regions that require assistance in these areas. As one Member of Parliament asserted, "selling the Gripen is a great national branding strategy. We do not just sell planes, we sell education and we sell other business components that can really help the buying country especially if it is a developing economy". 92

Notwithstanding these 'noble' attempts to spread so-called socio-economic development, the political and economic importance of supporting indigenous military production and the anticipated benefits of arms exports have consequently 
led to the loose implementation of formal policy. As Goldmann states, "Sweden sells arms to support a national weapons industry thought to be essential for maintaining the credibility of its neutrality policy; this may seem difficult to reconcile with its preaching of peace and disarmament."93 Yet despite these unambiguous paradoxes in Sweden's nation branding, it continues to attract and seduce potential partners successfully based on its ideals-driven national identity. And although these paradoxes have not gone unnoticed by Sweden's cooperating partners, they seem to have little, if any, negative effects. As a deputy director at the Department of Trade and Industry in South Africa made quite clear:

Sweden is in South Africa for political and economic reasons, and strategically that is quite sound. There is a selfish role or reason in all of this of course. The money they spend does after all come from their taxpayers' pockets. In this regard, Sweden is very similar to many other countries. I think any government that sells defence products to another country must have strategic and political reasons for operating there. That being said, Sweden is not as bad as many of the others. And even if Sweden were pushing their own agenda, it would not look half as bad as many other countries since we in South Africa quite like the way that they tend to do things. This has a lot to do with the fact that Sweden does not have a colonial history in Africa. ${ }^{94}$

It appears that Sweden's past is shaping its present and possible future for Gripen exports. History, as Merle Lipton reminds us, is after all an important part of any society's consciousness. It contributes to the beliefs of the society, shapes its understanding about itself and the world, and provides some indication of who its friends and enemies are. ${ }^{95}$

\section{Conclusion}

This article attempted to provide a deeper understanding of Sweden's Gripen exports by analysing the variation and configuration of societal preferences, policy shifts vis-à-vis security and defence, and the role that national identity plays in Sweden's weapons exports. Although the study on which this article reported was empirically motivated, in other words, not structured around a specific theory-driven analytical framework, it nevertheless spoke to a broader literature on arms trade and foreign policy and it highlighted, albeit indirectly, some important conceptual issues.

From an economic perspective, the article illustrated that certain societal actors and the state favour the export of the Gripen since it opens up the possibilities for transnational industrial participation, greater market access, increased 
competence, sustained employment, reduced costs and the posited economic growth that comes from trade. This has also allowed for collaborative business ventures connected to offsets and technology transfers that the industrial base in Sweden can offer. In that sense, a Gripen deal with Sweden is more than just a procurement package for military hardware; it is a broad-based business venture that connects various interrelated sectors domestically and transnationally. More specifically, it provides an entry point for Swedish companies to gain access to other markets thereby strengthening and elevating the economic relations with the buying country.

From a security perspective, the end of the Cold War and the changed strategic global conditions provided an opportunity for the Swedish government to transform the former security doctrine of that country - based largely on independence - and engage more actively in unguarded security and defence cooperation with international partners both inside and outside of Europe. In this context, the article also showed that defence and security transformation during that period was significant for the Gripen programme regarding internationalisation and exports. At the same time, the article highlighted the important role that the Swedish state has played in creating and maintaining markets for defence firms, such as SAAB.

In addition to these 'hard aspects', the article also illustrated that the export and acquisition of the Gripen is not merely interest-driven but ideational factors also play a central role in these matters. A very clear example of this is the way in which different notions of 'Swedishness' or Swedish national identity help shape the relationship between actors within Sweden and the seductiveness this holds for potential buyers of the Gripen. Another good example is Sweden's technology transfers. This generous sharing of knowledge and management assistance is a unique feature of Sweden's weapons exports. In that sense, Sweden has refrained from the hard protectionist and zero-sum approach by opting for a more internationalist long-term cooperative approach. This also illustrates that Sweden's defence industry is selling more than an aircraft; it is selling an idea - in this case, a quintessential liberal idea based on solidarity, cooperation, peace and development, and a foundation of moral conviction and progress.

In conclusion, this study demonstrated that in real-world politics and in defence-related matters, there could be a close interaction between interest-driven and ideals-driven factors. These two aspects do not always operate in isolation and the one often needs the other. Sweden's ability to balance these two aspects is one of its greatest strengths, and it is the awkward yet effective relationship between these forces that helps us understand Sweden's Gripen exports. 


\section{Endnotes}

${ }^{1} \mathrm{PhD}$ Candidate at the School of Global Studies, University of Gothenburg; and Lecturer in Political Science at University West, Trollhättan. This article is broadly based on the author's PhD research which examines ideals and interests in Swedish foreign policy as it relates to the Gripen deal with South Africa (expected completion 2018). Interviews conducted with former and current high-ranking officials and experts in government; government agencies and ministries; parliament; the defence sector; trade unions; and two civil society organisations are concealed where necessary.

${ }^{2} \mathrm{SAAB}$ is the acronym used for Svenska Aeroplan Aktiebolag.

3 The Gripen is often referred to as 'Griffin' in English. The Swedish acronym JAS (jakt, attack och spaningsuppdrag) translates to "hunting, attack and reconnaissance".

4 These include Slovakia, Malaysia, India, Croatia, Portugal, Chile, Peru and Mexico.

5 According to SIPRI's Trend Indicator Values (TIVs), Sweden was the $12^{\text {th }}$ largest weapons exporter in the world between 1991 and 2016. Aircraft has accounted for the largest share of Swedish weapons exports since 2003. Between 2008 and 2012, Sweden was the seventh largest supplier of aircraft in the world. See SIPRI Arms Transfers Database: https://www.sipri.org/databases/armstransfers

${ }^{6}$ U Bjereld \& U Möller. "Swedish foreign policy: The policy of neutrality and beyond." In J Pierre (ed), The Oxford handbook of Swedish politics, New York, NY: Oxford University Press, 2016.

${ }^{7}$ US Congress. Global arms trade. Washington, DC: US Government Printing Office, 1991.

${ }^{8}$ N Stenlås. Technology, national identity and the state: Rise and decline of a small state's military-industrial complex. Stockholm: Institute for Future Studies, 2008.

${ }^{9}$ B von Sydow, personal interview, April 2016.

${ }^{10}$ SOFF, personal interview, January 2015.

11 Von Sydow op. cit.

12 I Carlsson, personal interview, October 2015.

13 Von Sydow op. cit.

14 IFMetall. 2016. <http://www.ifmetall.se/> Accessed on 27 March 2016.

15 Sveriges socialdemokratiska arbetareparti, which in English translates to "Social Democratic Worker's Party of Sweden".

16 The Social Democrats dominated Sweden's political apparatus for nearly 40 years. See K Östberg. "Swedish social democracy after the Cold War". In B Evans \& I Schmidt (eds), Social democracy: After the Cold War, Edmonton: AU Press, 2012; G Gidlund. "From popular movement to political party: Development of the Social Democratic Labour Party Organization”. In K Misgeld, K Molin \& K Åmark (eds), Creating social democracy: A century 
of the Social Democratic Labor Party in Sweden, Philadelphia, PA: The Pennsylvania University Press, 1992.

$17 \mathrm{~K}$ Åmark. "Social democracy and the trade union movement: Solidarity and the politics of self-interest". In Misgeld et al. op. cit.

18 Personal interview, April 2016.

19 Personal interview, March 2016.

20 Personal interview, April 2016.

21 PM Haas. Knowledge, power, and international policy coordination. Columbia, SC: University of South Carolina Press, 1997.

${ }^{22} \mathrm{~L}$ Åkerström, personal interview, April 2016.

23 Personal interview, October 2012.

${ }^{24}$ C Wright Mills. The power elite. New York, NY: Oxford University Press, 1956.

${ }^{25}$ Folk och Försvar (Society and Defence) is a platform for public discussion on security and defence policy. The annual national conference is the foremost meeting place for the Swedish security and defence policy community.

${ }^{26}$ Personal interview, March 2016.

27 T Larsson \& H Bäck. Governing and governance in Sweden. Budapest: Elanders Hungary, 2008, 15.

28 Personal interview, April 2016.

29 J Lindvall \& J Sebring. "Policy reform and the decline of corporatism in Sweden". West European Politics 28. 2005. 1057-1074.

${ }^{30}$ B Huldt. "Swedish commentator". In E Munro (ed), Challenges to neutral and non-aligned countries in Europe and beyond, Geneva: Geneva Centre for Security Policy, 2005.

31 Swedish Member of Parliament, personal interview, March 2015.

32 Personal interview, March 2016.

${ }^{33}$ U Olsson. The creation of a modern arms industry: Sweden 1939-1974. Gothenburg: Berlinska Boktryckeriet, 1977; M Ikegami-Andersson. The military-industrial complex: The cases of Sweden and Japan. Boston, MA: Dartmouth, 1992; JM Feldman. "A model of Swedish security policy: Deconstructing 'the Swedish paradox"'. Paper presented at the 17th Annual Conference on Economics and Security, Stockholm, 2013; B Hagelin. "Arms transfer limitations: The case of Sweden". In T Ohlson (ed), Arms transfer limitations and Third World security, Stockholm: SIPRI, 1988; B Hagelin. Neutrality and foreign military sales: Military production and sales restrictions in Austria, Finland, Sweden, and Switzerland. San Francisco, CA: Westview Press, 1990; M Bromley \& S Wezeman. Current trends in the international arms trade and implications for Sweden. Stockholm: SIPRI, 2013.

${ }^{34} \mathrm{~N}$ Andrén. Maktbalans och alliansfrihet: svensk utrikespolitik under 1900-talet. Stockholm: Norstedts Juridik, 1996; O Kronvall \& M Petersson. Svensk säkerhetspolitik i supermakternas skugga 1945-1991. Stockholm: Santérus Academic Press, 2012.

35 Personal interview, March 2016.

36 C Agius. "Transformed beyond recognition? The politics of post-neutrality". Cooperation and Conflict 46. 2011. 370-395. 
${ }^{37}$ M Petersson. "Defense transformation and legitimacy in Scandinavia after the Cold War: Theoretical and practical implications". Armed Forces \& Society 37. 2011.701-724; JJ Andersson. "A new Swedish defence for a brave new world”. In JH Matlary \& Ø Østerud (eds), Denationalisation of defence: Convergence and diversity, Aldershot: Ashgate, 2007; J Ångström. "Försvarsmaktens internationella insatser: i den svenska säkerhetens eller identitetens tjänst?’ In K Engelbrekt \& J Ångström (eds), Svensk säkerhetspolitik i Europa och världen, Stockholm: Nordstedts Juridik, 2010.

38 J Berndtsson, C Dandeker \& K Ydén. "Swedish and British public opinion of the armed forces after a decade of war". Armed Forces \& Society 41. 2015. 307-328.

39 SOFF op. cit.

${ }^{40}$ FOI, personal communication, April 2016.

41 Government Bill, 1991/1992: 74; Foreign Affairs Committee Report, 1992/1993: UUI.

${ }^{42} \mathrm{M}$ Britz. "The role of marketization in the Europeanization of defense industry policy”. Bulletin of Science, Technology \& Society 30. 2010. 176-184.

43 Andersson op. cit.; B Hagelin. "Saab, British aerospace and the JAS 39 Gripen Aircraft Joint Venture”. European Security 7. 1998. 91-117; M Ikegami. "The end of a national defence industry: Impacts of globalization on the Swedish defence industry". Scandinavian Journal of History 38. 2013. 436457.

44 Government report to Parliament, Swedish Arms Exports, 1998/99:128.

45 Foreign technologies and cooperation in R\&D of Swedish aircrafts, in particular from the USA and Britain, were a practice that was largely kept secret during the Cold War. See R Dalsjö. Life-line lost: The rise and fall of "neutral" Sweden's secret reserve option of wartime help from the West. Stockholm: Santéreus Academic Press, 2006.

46 Government report op. cit.

${ }^{47} \mathrm{~K}$ Hartley. The political economy of aerospace industries: A key driver of growth and international competitiveness? Cheltenham: Edward Elgar, 2014, 238.

48 B Hellenius. "Griffen takes wing: SAAB JAS 39 Gripen”. Air Forces Monthly. 2014. 50-73. [March]; A Kruger. "SA's arms scandal: Why SA had to buy the Gripen”. Institute for Security Studies. 2011. <https://www.issafrica.org/iss-today/sas-arms-scandal-why-sa-had-to-buythe-gripen> Accessed on 7 March 2016.

49 FMV, personal communication, March 2016.

50 J Erasmus. "Gripen first for SA woman fighter pilot”. South Africa Info. 2010. <http://www.southafrica.info/about/people/catherine-labuschagne.htm.V4y8TK78mCU> Accessed on 17 September 2012.

51 RRV. Vad Kostar JAS 39 Gripen? Rapport om Gripenprojektets ekonomi. Stockholm: Government of Sweden, 1996.

52 A Moravcsik. "Armaments among allies: European weapons collaboration, 19751985”. In P Evans, H Jacobson \& R Putnam (eds), Double-edged diplomacy: International bargaining and domestic politics, Berkeley, CA: University of California Press, 1993, 128. 
${ }^{53}$ G Eliasson. Advanced public procurement: The aircraft industry as a technical university. New York, NY: Springer, 2010.

${ }^{54}$ Ibid.

55 Government Defence Bill, 1996/97:4.

56 I Davis. The regulation of arms and dual-use exports: Germany, Sweden and the

UK. Oxford: Oxford University Press, 2002, 195.

57 Von Sydow op. cit.

58 Carlsson op. cit.

59 A Ek, personal interview, September 2013.

60 Swedish Member of Parliament, personal interview, October 2012.

61 Davis op. cit., p. 193.

62 Personal communication, January 2015.

${ }^{63} \mathrm{M}$ af Malmborg. Neutrality and state-building in Sweden. Houndsmills: Palgrave, 2002.

64 Personal interview, January 2015.

65 Personal interview, February 2015.

${ }^{66} \mathrm{~K}$ Krause. Arms and the state: Patterns of military production and trade.

Cambridge: Cambridge University Press, 1992.

67 W Hartung. "The international arms trade". In PD Williams (eds), Security studies: An introduction, New York, NY: Routledge, 2013, 439-456.

$68 \mathrm{~V}$ Nadkarni \& NC Noonan. Emerging powers in a comparative perspective: The political and economic rise of the BRIC countries. New York, NY:

Bloomsbury, 2012.

69 Personal interview, January 2015.

70 S Ferreira, personal interview, May 2015.

71 D Eyre \& M Suchman. "Status, norms and the proliferation of conventional weapons: An institutional theory approach". In P Katzenstein (eds), The culture of national security, New York, NY: Columbia University Press, 1996, 86.

72 Personal interview, May 2016.

73 Personal interview, March 2016.

74 SOFF op. cit.

75 Von Sydow op. cit.

${ }^{76}$ Carlsson op. cit.

77 Personal interview, May 2016.

78 Volvo executive, personal communication, May 2014.

79 SOFF op. cit.

${ }^{80}$ D Brommesson. Från Hanoi till Brysel: Moralsyn I deklarerad svensk utrikespolitik 1969-1996. Gothenburg: Gothenburg University Press, 2007.

81 A-S Dahl. "Sweden: Once a moral superpower, always a moral superpower". International Journal 61. 2006. 895-908.

$82 \mathrm{~S}$ Engh. "The conscience of the world: Swedish and Norwegian provision of development aid". Itinerario 33. 2009. 65-82.

83 SMFA. Swedish development cooperation with South Africa, January 1999 December 2003. Ministry of Foreign Affairs. Stockholm: Government of Sweden, 1999; $\quad$ SMFA. Swedish development cooperation with South 
Africa, July 2004 - December 2008. Ministry of Foreign Affairs. Stockholm: Government of Sweden, 2004.

${ }^{84}$ Economic offsets have been a point of controversy in the Gripen deal with South Africa. The SAP and SAAB argued that South Africa would benefit financially from offset projects that would be generated through a joint Gripen programme. The beneficiaries of this wealth would be the poor masses in South Africa, especially black South Africans. There is scant evidence to support such claims, and the lion's share of the wealth, it must be assumed, has been distributed among those who vigorously campaigned for the deal. From the outset, the Gripen deal with South Africa was plagued by allegations of corruption between South African and Swedish elites. Several politicians, economists and academics have argued that the deal was suspiciously expensive, irrational and even reckless. See $\mathrm{P}$ Holden \& $\mathrm{H}$ van Vuuren. The devil in the detail: How the arms deal changed everything. Johannesburg: Jonathan Ball, 2011.

85 N Resare. Mutor, makt och bistånd: Jas och Sydafrikaaffären. Stockholm: Natur \& Kultur, 2010, 10; See also Swedish Parliament Protocol, 2000/01:106.

${ }^{86}$ Swedish Parliament Protocol op. cit.

${ }^{87}$ Eliasson op. cit.

88 J-P Dunne \& G Lamb. "Defence industrial participation: The South African experience". In J Brauer \& J-P Dunne (eds), Arms trade and economic development: Theory, policy, and cases in arms trade offsets, London: Routledge, 2004.

${ }^{89}$ Hagelin, "Saab, British aerospace ..." op. cit.

90 Personal interview, September 2015.

91 Personal interview, May 2015.

92 Personal interview, January 2015.

93 K Goldmann. "The Swedish model of security". West European Politics 14. 1991. 122-143.

94 N Vereen, personal interview, May 2015.

95 M Lipton. Liberals, Marxists, and nationalists: Competing interpretations of South African history. New York, NY: Palgrave Macmillan, 2007. 